\title{
COVID-19 is catalyzing the adoption of teleneurology
}

Brad C. Klein, MD, MBA, and Neil A. Busis, MD

Neurology ${ }^{\circledR}$ 2020;94:903-904. doi:10.1212/WNL.0000000000009494

The coronavirus disease of 2019, or COVID-19, changed the world within a matter of weeks. The primary action to constrain the spread of the virus is social isolation. Given this public health principle, and the shortage of personal protective equipment during the global pandemic, all health care stakeholders need to reconsider the indications for face-to-face health care encounters in providing patient care. Which encounters are imperative and which ones can be switched to non-face-to-face care? What changes in laws, regulations, payment policies, and workflow are needed to enable this transition $?^{1-3}$

Remote or non-face-to-face care models, in which the patient is geographically separated from the physician or other qualified health care professional, are enabled by communication-based technologies. They have existed for decades, but widespread implementation has been constrained by laws, regulations, and policies at national, state, and organizational levels. Federal and commercial payers have not covered many of these services. Until recent years, the evidence for their effectiveness compared with traditional care models has been sparse. ${ }^{4,5}$

The general terms for many non-face-to-face care services are "telehealth" or "telemedicine," from the Greek word for "far." Many think of telemedicine as consisting exclusively of real-time interactive or synchronous audio and video communications between a patient and a provider. There is a wide spectrum of other telehealth services including telephone communication; asynchronous digital services including email, text messages, and remote monitoring of patient data such as images or physiologic parameters; and provider-to-provider communications. ${ }^{6}$

Many evaluation and management services can be performed remotely. The first use of telemedicine in neurology was in stroke evaluation at hospitals where neurologists were not onsite. Evidence showed noninferiority of telestroke evaluations compared with face-to-face encounters. Today, "teleneurology is neurology" in a wide variety of clinical settings. ${ }^{7}$

The COVID-19 crisis stimulated policy makers, regulators, and payers to encourage expanded use of remote health care. Policy restrictions were loosened or lifted. Many telehealth services are now reimbursed with few associated administrative burdens. Neurologists, regardless of setting, should consider incorporating telehealth into their practice. It is imperative to rapidly understand current local and federal laws, regulations, and coding and reimbursement options and stay informed because laws, regulations, and reimbursements may change by the day. For example, providers may now be reimbursed for Medicare patients using traditional evaluation and management coding for telehealth visits regardless of patient location, including the patient's home. ${ }^{8}$ Per Centers for Medicare and Medicaid Services, providers licensed in any US state may now practice telehealth in other states without additional licensing, if state laws allow this. ${ }^{9,10}$

Providers must remain vigilant to understand their state's laws and each individual payer's policies including use of modifiers and eligible patient populations. Payments by payers within a state vary based on existing parity laws, ${ }^{10}$ temporary mandates during the emergency period of COVID-19, contract negotiations, and individual payer policy decisions. Furthermore, these rules and regulations may change frequently requiring practices to rereview their contracted payer websites, contacting the payers directly, and/or reaching out to their state medical or neurologic societies. The American

\section{Correspondence}

Dr. Klein

bradcklein@gmail.com

\section{MORE ONLINE}

COVID-19 Resources

For the latest articles, invited commentaries, and blogs from physicians around the world

NPub.org/COVID19 
Academy of Neurology has developed online resources on how to provide telemedicine and remote care services ${ }^{11}$ and telehealth coding. ${ }^{12}$ The information will be regularly updated.

Although COVID-19 did not alter telehealth-related Current Procedural Terminology, new non-face-to-face service codes were added in $2020 .{ }^{12}$ Practices can benefit from refocusing efforts and fully understanding the spectrum of telehealth codes. Providers may be paid not only for traditional telemedicine but also for evaluation and management services based on online work, interprofessional consults, or telephone encounters. ${ }^{6,12}$ However, practices must diligently review each contracted payer's policies to determine applicable payments. Developing a telehealth-based fee schedule to understand coding and reimbursement implications across payers may help administration and providers.

Workflow and staffing functions need to adapt to telehealth services as well. Staff needs to support scheduling. Technology needs to integrate electronic medical records with telehealth applications if practical and ensure that providers and patients can connect with one another via the telehealth platform. Billing, prior authorizations, managerial oversight, and additional clinical concerns such as prescribing need to be addressed. Depending on the size of one's organization and staffing capabilities, there may be value in creating rotating teams to manage clinic functions in the office or via telehealth. Student and resident education must also be reconfigured to consider their roles whereby they may still see patients via telehealth supervised by the attending to discuss best clinical management.

Providers, administrators, hospitals, and networks will benefit from developing models in telehealth to project the economic impact on their practices and institutions. Depending on the organization size and structure, they may need access to cash and consider overhead reductions to keep their doors open if reserves dwindle due to diminished reimbursements. Consideration should also include small business loans, lines of credit, or other options. Department leadership should be ready for conversations with their hospital or enterprise leadership about projections and ramifications. A sensitivity analysis should consider the impact of an ongoing crisis that may last weeks to months.

In parallel, practices should begin considering what a postCOVID-19 world may look like. The impact of telemedicine in practices is unlikely to recede as this changing paradigm will leave an indelible imprint on new and valued opportunities of care between providers and patients. As practices build or enhance their telemedicine capabilities, they may benefit from ensuring that their model is built on a strong, reliable infrastructure, with the ability to scale, and become embedded within normal operations after the crisis resolves. ${ }^{13}$

Over time, leadership will also want to understand each provider's strengths and weaknesses associated with telehealth for ongoing utilization. Telemedicine is a specific audiovisual communications technology, requiring authentic engagement and rapport, provider and patient placement, room staging, nonverbal communication strategies, appropriate documentation, and time management. ${ }^{14}$ Not every neurologist may be comfortable with performing a high volume of telemedicine services due to lack of social interaction with colleagues.

The global pandemic will have a lasting effect on society. If there are positive consequences to be considered, they could include a stronger sense of community and ongoing dissemination and implementation of telehealth services that improve population health, patient care, and lower costs.

\section{Study funding}

No targeted funding reported.

\section{Disclosure}

B.C. Klein has received honoraria for speaking at American Academy of Neurology courses and serves on the speaker's bureau of Allergan, Amgen, Biohaven, Eli Lilly, Teva, US WorldMeds, and West Lundbeck. He has served as consultant for Allergan, Amgen, Promius, and Biohaven. He has received commercial research support from Alder, Allergan, and Eli Lilly. Dr. Klein has equity interest in Abington Neurological Associates, Ltd. and AppsByDocs, LLC. B.C. Klein is a member of the American Academy of Neurology Board of Directors. N.A. Busis receives honoraria for speaking at American Academy of Neurology courses and for serving as Alternate CPT Advisor for American Academy of Neurology and is a former member of the American Academy of Neurology Board of Directors. Go to Neurology.org/N for full disclosures.

\section{References}

1. Hollander JE, Carr BG. Virtually perfect? Telemedicine for Covid-19. N Engl J Med Epub 2020 March 11.

2. Lurie N, Carr BG. The role of telehealth in the medical response to disasters. JAMA Intern Med 2018;178:745-746.

3. American Telemedicine Association. COVID-19 (Coronavirus) News, Information \& Resources. Available at: info.americantelemed.org/covid-19-news-resources. Accessed March 24, 2020.

4. Wechsler LR. Advantages and limitations of teleneurology. JAMA Neurol 2015;72: 349-354.

5. Hatcher-Martin JM, Adams JL, Anderson ER, et al. Telemedicine in neurology: Telemedicine Work Group of the American Academy of Neurology update. Neurology 2020;94:30-38.

6. American Medical Association. 2020 CPT Professional Edition. Chicago, IL: American Medical Association; 2019.

7. Guzik AK, Switzer JA. Teleneurology is neurology. Neurology 2020;94:16-17.

8. HHS Issues Section 1135 Waiver, and CMS Issues Blanket Waivers of Health Care Laws, in Response to Coronavirus (COVID-19) Emergency. Available at: natlawreview.com/article/hhs-issues-section-1135-waiver-and-cms-issues-blanket-waivershealth-care-laws. Accessed March 21, 2020.

9. Center for Connected Health Policy. Telehealth Coverage Policies in the Time of COVID-19. Available at: cchpca.org/resources/covid-19-telehealth-coverage-policies. Accessed March 21, 2020.

10. Lacktman NM, Acosta JN, Levine SJ. 50-State Survey of Telehealth Commercial Payer Statutes. Foley.com/Telemedicine, December 2019. Available at: foley.com/-/ media/files/insights/health-care-law-today/19mc21486-50state-survey-of-telehealth-commercial.pdf. Accessed March 21, 2020.

11. American Academy of Neurology. AAN Telemedicine and Remote Care Website. Available at: aan.com/telehealth. Accessed March 21, 2020.

12. American Academy of Neurology. Procedure Coding for Telemedicine Visits Available at: aan.com/siteassets/home-page/tools-and-resources/practicing-neurologist-administrators/telemedicine-and-remote-care/20-telemedicine-cpt-codes-anddescriptors.pdf. Accessed March 21, 2020.

13. Duffy S, Lee TH. In-person health care as option B. N Engl J Med 2018;378:104-106.

14. National Consortium of Telehealth Resource Centers. NCTRC Webinar - Telemedicine: How to do it Right! 2019. Available at: telehealthresourcecenter.org/ events/category/webinars/list/?tribe_event_display=past\&tribe_paged=2: the future of neurological care. Accessed March $25,2020$. 


\section{Neurology}

\section{COVID-19 is catalyzing the adoption of teleneurology}

Brad C. Klein and Neil A. Busis

Neurology 2020;94;903-904 Published Online before print April 1, 2020

DOI 10.1212/WNL.0000000000009494

\section{This information is current as of April 1, 2020}

Updated Information \& Services

References

Citations

Permissions \& Licensing

Reprints including high resolution figures, can be found at: http://n.neurology.org/content/94/21/903.full

This article cites 5 articles, 2 of which you can access for free at: http://n.neurology.org/content/94/21/903.full\#ref-list-1

This article has been cited by 8 HighWire-hosted articles: http://n.neurology.org/content/94/21/903.full\#\#otherarticles

Information about reproducing this article in parts (figures,tables) or in its entirety can be found online at:

http://www.neurology.org/about/about_the_journal\#permissions

Information about ordering reprints can be found online:

http://n.neurology.org/subscribers/advertise

Neurology ${ }^{\circledR}$ is the official journal of the American Academy of Neurology. Published continuously since 1951, it is now a weekly with 48 issues per year. Copyright (C 2020 American Academy of Neurology. All rights reserved. Print ISSN: 0028-3878. Online ISSN: 1526-632X.

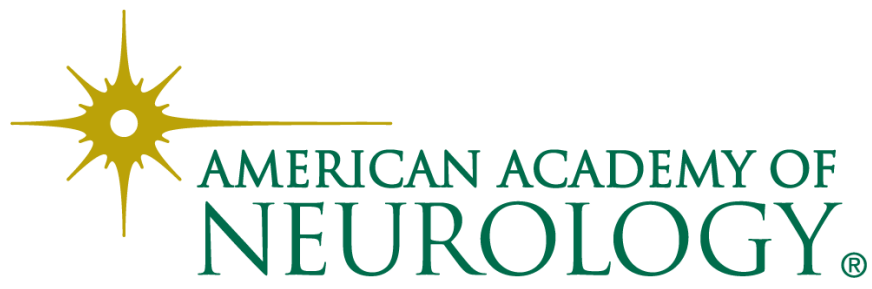

